\title{
The Effect of the Congruence between Brand Personality and Self-Image on Consumer's Satisfaction and Loyalty: A Conceptual Framework
}

\author{
Mohamed Ali ACHOURI and Néji BOUSLAMA \\ the FSEG of Tunis, Tunisia
}

\begin{abstract}
This research belongs to the field of the analysis of the consequences of congruence between brand personality and self-image. The consequences taken into account in this study are consumer's satisfaction and loyalty. We will present a literature review on the study of impact of the congruence between brand personality and self-image on the four dependant variables considered in this research: Satisfaction, attitude, preference and behavioural intentions.
\end{abstract}

Keywords: Congruence, Brand personality, Self-image, Satisfaction, Loyalty.

\section{Introduction}

The saturation of markets, the congestion of the advertising landscape, and the maturity of the consumers towards the brands have urged companies to go beyond the image brand to the relation brand (Samama, 2003), in order to preserve their market shares. Keeping their shares in the market is linked to the level of their customers' faithfulness. Besides, nowadays consumers tend, for their decisions, to rely on the brand image as it is developed in their mind rather than on the inherent attributes and characteristics of the product (Dich et al., 1990). This turns customer loyalty into a major primary marketing objective (Benavant, 1995; Trinquecoste, 1996).
Marketing researchers have shown a marked interest in the concepts and the mechanisms which are likely to increase the understanding of the brand-consumer relation. One of these key concepts in relational marketing is the congruence between the brand personality and the consumer's self-image. In fact, it counts among the strategic tools which allow to understand the analogy between the human being and a given brand. Associating the specific personality features to the brands allows the consumer to express a certain conception of himself, so as to acquire some value-enhancing, symbolic benefits from a given consumption (Vernette, 2003).

Our current study is situated within the framework of the effort to understand the impact of the congruence between the 
personality of a brand and the consumer's selfimage on his behavior. More precisely, we will evaluate the effect of this congruence on the consumer's satisfaction and loyalty to the brand. We will first provide an overview of the state of the research undertaken on the congruence between brand personality and self-image, notably in regard to the central variables of our model, namely the consumer's satisfaction and loyalty. We will, then, propose a model and some hypotheses.

\section{Human personality and brand personality: clarifying concepts The human personality: the origin of the personality of the brand.}

Numerous research works have been conducted in the field of Humanities, especially in applied psychology, aiming at conceptualizing and structuring the human personality according to a number of characteristic dimensions. While not referring to the concrete individual, this abstract concept is inferred from the way the individual behaves and reacts to his environment (Koebel and Ladwein, 1999).

Personality is a psychological notion, often presented as a stable and individualized unity of a set of behaviors (Huteau, 1985) or as a structure of features (Ambroise et al., 2003). The features are defined as "tendencies to show coherent modes of cognition, affective perception and behavior on the part of the individual" (Costa and McCrae, 1998); or as "a lasting aspect of the individual personality which influences behavior in a particular field" (Cloninger, 1999). Taken globally, the personality features must be perceived as stable psychological characteristics which give meaning to human action and experience.

For many years, personality psychologists have tried to determine the number and the nature of the main dimensions which are necessary for the description of the features of the human personality. Seeing the abstract nature of this personality, measuring its features has constituted a research topic for researchers and practitioners. Several types of scales have been proposed and tested. Ambroise et al., (2003) have mentioned the Thurstone (1953) constitution scale, the "Cattell Personality Factor Inventory" (1957), "Edwards Personal Preference Schedule" (1959), or the "Gordon Personality Profile" (1963). More recently, most authors have become convinced that the best representation of the structure of the personality features is provided by the "Big FiveModel" (Digman, 1990; Goldberg, 1990; 1992; John, 1990; Funder, 2001).

Identifying the Big Five Model has been a crucial discovery in psychology. Devised according to a psycho lexical approach, this model has allowed to unify a rich literature on the personality features (Plaisant et al., 2005), and has become the most dominant and widely used model. Caprara et al., (1994) emphasize the fact "the strength of the five-factor model lies essentially in its application. This model can notably constitute a link between personality psychology and social psychology and equally between the researchers and practitioners facing the problem of personality description". The description of the personality features will proceed from the five fundamental factors, known as the abbreviation OCEAN:

-Factor "O": Open-mindedness vs narrowmindedness, i.e. intellectual curiosity, imagination, opening to new experiences.

- Factor "C": Conscientious trait, i.e. orientation, lasting behavior and mastering impulsions.

- Factor "E": Extraversion vs introversion: leading back to the quality and the intensity of the relations with the environment.

-Factor "A": Friendliness and pleasantness: concerning the relation with others.

-Factor "N": Neuroticism or emotional stability: the person is balanced, optimistic, quiet and feeling positive emotions.

From the human personality to the brand personality: a metaphorical transfer

During the previous years, brands have become more and more customized (Plummer, 1985; Levy, 1985; Durgree, 1998; Berry, 1988). The measurement scales developed in human personality psychology have been transferred to the brands. This transfer does not rely on an explicit theoretical referent, but on a metaphor 
whereby the brand is considered as a person, and is thus given a number of attributes which are habitually given to individuals (Viot, 2006).

\section{The concept of brand personality}

Even though the study of the brand has been the focus of many works, this field has not yet been fully investigated (Ambroise et al., 2003). In fact, there is no agreement around the conceptualization, the measures or the components of this construct.

In his works, Aaker (1997) defines brand personality as being "a set of human characteristics associated to a brand". The author postulates that it can include certain characteristics such as age, socio-economic class, personality traits and feelings. She developed a model of measurement of the personality of a brand by identifying 42 features divided up among 15 facets and 5 factors of personality: sincerity, excitement, competence, sophistication and ruggedness. However, Aaker's founding definition has often been criticized.

Viot (2006) postulates that starting from this definition, the brand personality has become a jumble concept. According to Azoulay and Kapferer (2003), Aaker defines brand personality, not uniquely as a facet of identity, but as a much more global construct. Both authors conceptualize brand personality as " the set of traits of human personality which are pertinent and applicable to brands". Ambroise et al., (2003) also find this definition too global as it can comprise some brand personality traits which have no equivalents at the human level ; and also because it can present some personality features which rather correspond to social judgments (provincial, trendy, or aristocratic). Thus, the authors think that it is fairer to define brand personality as being "the set of traits of human personality associated to a brand".

\section{Measuring brand personality}

Despite the clarifications made by different authors concerning the brand personality, measuring this concept has remained a study topic for researchers and practitioners. This is notably due to the abstract nature of the concept and to the difficulty of validating the obtained scales at an intercultural level.

Ambroise et al., show that all the existing scales for measuring brand personality have been elaborated from human personality measurement scales. Aaker (1997) proposed the first theoretical model of the concept of brand personality by determining the number and the nature of its dimensions. This model relies on a hierarchical approach similar to those developed in personality psychology (Ambroise, 2004).

Ambroise et al., show that all the existing scales for measuring brand personality have been elaborated from human personality measurement scales. Aaker (1997) proposed the first theoretical model of the concept of brand personality by determining the number and the nature of its dimensions. This model relies on a hierarchical approach similar to those developed in personality psychology (Ambroise, 2004).

Thus, in a cross-categorical framework, and starting from the inventory of Goldberg (1990), Aaker identifies five dimensions according to which a brand could be described, namely, sincerity, excitement, competence, sophistication, and ruggedness. This primarily North American scale has proved to be a flexible measuring tool which is adaptable according to the products categories (Smaoui, 2006). It has made it possible to discriminate different product or services (Aaker et al., 2001; Bauer et al., 2000; Ferrandi et al., 1999; Koebel and Ladwein, 1999). It has been used by different researchers during the study of the consequences of brand personality (Koebel and Ladwein, 1999; Sigaw et al., 1999; D'Astous et al., 2002/2003; Vernette, 2003; Diamantopoulos, 2005).

Within the same line of Aaker's works, the scale has been applied, tested and validated in other cultures. Ambroise et al., (2003) have synthesized the different transpositions of Aaker's scale in different cultural contexts.

These works have shown that Aaker's scale is transposable, totally pioneer and widely 
recognized, but that it suffers a number of failings. Its structural and semantic validity is questioned, notably when it comes to the generalization of the scale in culturally different contexts (Ambroise et al., 2003).

Some authors have attempted to transpose human personality scales on brands: Caprara and Barbaranelli(1994,2001) have followed a lexical approach which consists in elaborating, within an Italian context, a scale for measuring human personality and then transposing it to brands. Their results are little convincing (Smaoui, 2006). On their part, Ferrandi and Valette-Florence (2002b) started from the list of adjectives related to human personality made by Saucier (1994). Their results are rather conclusive as they find out, like Saucier, a fivedimensional structure for the two fields of application of the scale (Ambroise et al., 2003)

Other authors (Viot, 2003; Ambroise et al., 2003, 2004,2005 ) have developed specific barometers for the description of brands, as the "analogy between human personality and brand personality is not enough to impose on the brand the same dimensionality which the human personality admits" (Bahria and Bouslama, 2009).

The Viot scale displays three dimensions: pride, conviviality, and the competence-excitement dimension. Ambroise et al. (2004) have been able to purify the list of the brands specific qualifiers in order to build a measuring barometer with a 12-facet and 33-item structure.

On her part, Smaoui (2006) has devised a measurement scale of brand personality which is particular to the Tunisian context. She followed three steps: the generation of qualifiers, the selection of qualifiers, and the purification of the scale. This scale has five dimensions: excitement, sincerity, refinement, belonging and conviviality.

\section{The congruence between brand personality and self-image}

The notion of self-image started to emerge in the marketing field in the mid 1960's and flourished in the mid 1970's. The studies focusing on the consumer's behavior were interested in clarifying the links that an individual seeks to create between the image he has of a product and his image of himself (Brée, 1994). These studies refer to the theory of self-image set up by motivationist psychologists, such as Rodgers and Maslow, and to Freud's work on the ego.

According to Vernette (2003), the definition of self-image is rather tricky because it entails taking position within a large number of paradigms.

L'Ecuyer (1978) suggests that this definition depends on the school of thought to whom it belongs, and Brunel (1990) states that there are as many definitions of self-image as there are psychological theories. For instance, there is the phenomenal self which is defined as an organized configuration of self perceptions that are accessible to conscience (Rodgers, 1959). On the opposite, there is the non phenomenal self, which is the main study focus of the psychoanalytical approach and which refers to the unconscious aspects. In social psychology, the self is perceived as a product of society that is through the social interactions which the individual introjects and the way others perceive him (Brunel, 1990).

According to L'Ecuyer (1994), the theory of selfimage refers to «the way a person perceives himself, to a set of characteristics, personal features, roles and values, etc. that the person attributes to himself, evaluates -positively or negatively- and recognizes as being part of himself, to the intimate experience of being and recognizing oneself despite changes».

Widely speaking, the notion of self-image is rather close to the notion of self-knowledge (Jamal and Good, 2001), because according to Brunel (1990), the definition of self-image requires a certain degree of self-knowledge. The author postulates that in order to be able to describe oneself, one needs to know oneself and that conscience and knowledge cannot be dissociated.

Later, to make things simpler, Vernette (2003) has considered that «self-image is based on an 
individual perception that is conscious and organized according to the way an individual defines himself and reacts towards his environment, while relying on his traits of personality, his values, his abilities and his experiences". The author equally thinks that selfimage implies a minimum level of introspection on the part of the individual, which should allow him to link his feelings and/or his behavior to this psychological organization.

\section{The dimensions of self-image}

Resermberg (1979) considers self-image as being the total sum of thoughts and feelings through which an individual can describe himself as an object. Building on this, Brunel (1990) has considered the concept of self-image as a multidimensional variable which comprises at the same time: a) a cognitive dimension, that is, the ideas, images and opinions an individual has of himself; b) an emotional dimension, that is, the impressions and the feelings he has towards himself; c) a social dimension, since the concept of self-image is a setting of projection of the others' perceptions of the individual. In the field of marketing, and more specifically in the field of research on the consumer's behavior, the concept of self is assimilated to the image of self in a rather diminishing way (Vernette, 2003). The concept of self is conceived of as a multidimensional notion involving different facets (Zouaghi and Darpey, 2003). Researchers have enriched this definition by identifying four dimensions of self-image (Sirgyet al., 1997; Jamal and Goode, 2001).

-The real self: the way an individual sees himself ("what I think I am").

-The dreamed self or the ideal self: the way I would like to be ("What I would dream to be").

-The real social self: the way others consider me ("what others think of me").

-The dreamed social self or the ideal social self the way I would like others to consider me ("what I would like others to think of me").

The advantage of this approach is that it makes it possible to figure out the interactions between the different dimensions of the self, and to look for congruence between the brand personality and the consumer's personality.
The importance of self-image in marketing

The managerial benefit of self-image is neither recent nor exceptional. In fact, among the individual factors accounting for the consumer's behavior, we find the notions of personality and self-image. Piéron (1994) stresses the fact that these notions are highly ranked as they represent the integrative unity of a person, together with the whole set of permanent differential characteristics and behavior modalities. Self-image, which we could theoretically substitute for human personality (Gouteron, 2006), can fairly predict future behaviors. It gives meaning to behavior motivations and leads them towards certain privileged objects, while keeping them away from others that will be rejected or ignored.

\section{Congruence: a crucial variable in marketing Congruence between brand personality and self-image}

Brand personality and self-image are two research tracks which increased our knowledge of the relationships between consumers and brands (Vernette, 2003). Sirgy (1982) explains that the concept of self-image is used as a cognitive referent in the evaluation of symbolic elements. The consumer seeks certain congruence between the features of a brand's image and the way his personality is presented (Belk, 1988; Sirgy, 1982). In other words, the consumer would express his self-image by choosing brands the personality of which appears to him close to his own personality (Vernette, 2008).

As a matter of fact, brands have an impact on the consumer's behavior, for the consumer compares his image to that of the brand, whether implicitly or explicitly. He often sets some imaginary relationships with it. He can situate himself in relation to a given brand through congruence, or lack of it, between his own personality and that which he attributes to a given brand (Plummer, 1985; Biel, 1993). 
Congruence with self-image is perceived as the similitude between the brand's symbolic attributes and the consumer's self-image (Munson and Spivey, 1981; Sirgy, 1982). Zinkhan and Hong (1991) define congruence as the degree of coincidence between advertising expression and self-image.

Within the framework of personal musical congruence, Galan (2007) defines congruence as being the adequacy or the coherence perceived between music and the consumer's self-image. The author suggests that it is possible for the individual to judge the congruence between selfimage and music.

Seeing that judging personal congruence relies on a four-dimensional concept of self, there are equally four types of congruence as defined in the literature (Sirgy, 1982; Helegeson and Supphellen, 2004; Galan, 2007):

- Congruence with the real self-image: it refers to the degree of similitude between the real selfimage of the consumer and the typical image the consumer has of the given product.

Led by their motivation to protect their own identity (Sirgy, 1982), individuals only consume the products which do reflect their genuine self (Galan, 2007).

- Congruence with the ideal image of self: it refers to the degree of similitude between the consumer's self-image and the image of the typical consumer of a given product. Behavior is then determined by a need of self-esteem. According to Galan (2007), reaching a certain ideal image of oneself through the consumption or the possession of products which are consistent with one's ideal self-image satisfies the consumer's need for self-esteem.

- Congruence with the social self-image: it corresponds to the degree of similitude between the consumer's social self-image and the image of the typical consumer. Such appropriateness satisfies a need for social coherence which is in fact a motivation to develop or keep attitudes and behaviors which cohere with the way others perceive an individual (Galan, 2007).

- Congruence with the ideal social self-image: it represents the degree of similitude between the consumer's ideal social self-image and the image of the typical consumer. Such congruence answers the individual's need for social approbation, or his need to develop a set of cognitions (Sirgy and Su, 2000).

- Congruence with the ideal social self-image: it represents the degree of similitude between the consumer's ideal social self-image and the image of the typical consumer. Such congruence answers the individual's need for social approbation, or his need to develop a set of cognitions (Sirgy and Su, 2000).

\section{Congruence in the other fields of marketing}

The analysis of the literature on congruence shows that researchers use this concept in many fields. This has allowed for an interesting explanation of this variable.

\section{Congruence in sponsorship}

The congruence between the sponsor and the sponsored entity has been investigated by numerous authors. However, the terminology applied has not always been the same (Trendel and Warlop, 2006). The authors talk of 'fit' (Speed and Thompson, 2000), of perceived similarity (Gwinner and Eaton, 1999; Louis, 2005), of pertinence (Rogers, 2004), of a semantic link between the sponsor and the sponsored entity (Johar and Pham, 1999), or they oppose a strong link between sponsor and sponsored entity to a certain congruence between both (D'Astous and Bitz, 1995).

Fleck (2004) defines congruence between sponsor and sponsored entity as being the degree to which the couple of sponsor/sponsored entity is perceived as fitting together. Speed and Thompson, (2000) have introduce the attitude variable and broadly define congruence as being the attitude towards associating the event and the sponsor, and the fact that this association is perceived as fitting or well-adapted.

A condition for the success of sponsorship lies in the existence of a logical link between the event and the sponsor's brand. Hence, sponsor and sponsored entity fit together because there is a link (Johar and Pham, 1999). This link will be all the more strengthened if the sponsor works in a 
field that is related to the nature of the sponsored event.

Gwinner and Eaton have established a distinction between congruence that is based on the characteristics of the image, and congruence that is based on functional characteristics. Crimmins and Horn (1996) distinguish natural congruence from congruence that needs an explanation through a specific communication.

Fleck (2005, 2006) studies congruence according to two dimensions: relevance on the one hand and what is expected from the sponsor/sponsored entity association on the other.

In the field of sponsorship, congruence evokes the strength of a tie linking the sponsor and the sponsored entity. Thus, congruence is presented as a determinant of the sponsoring efficiency, and as a variable that has been investigated by many authors.

Several authors have tackled the question of the number of dimensions this variable has. Thus, for parsimony and simplicity considerations, Speed and Thompson (2000) treat congruence as a one-dimensional variable, or as a sole construct. There are, however, many criteria which enable us to judge the logic behind the link between sponsor and sponsored entity. Taking these criteria into account has led some authors to distinguish several dimensions of congruence (Achouri and Bouslama, 2009).

In most studies on sponsorship, congruence between sponsor and sponsored entity is established on the basis of functional and symbolic characteristics, taking into account the distinction proposed by Heckler and Childers (1992), who depict congruence according to two dimensions: relevance on the one hand, and what is expected from the sponsor/sponsored entity association on the other. Louis (2005) talked about the similarity perceived between the sponsor and the sponsored entity. He stated two dimensions for similarity: it can be functional if both entities share functional attributes, that is, if the brand is really used by those taking part in the event. It can also be a similarity of image when the images of both entities are linked.

According to Fleck (2006), both the "relevant" and "expected" aspects of congruence are the most interesting aspects because they allow for a better understanding of the contradictory effects of congruence between sponsor and sponsored entity, and an explanation of efficiency through the level of elaboration of the treatment of the delivered information.

Congruence in the field of extending branding and co-branding

Many authors have worked on the variable of congruence in this field. According to Tauber (1988), there is congruence when the consumer accepts the new product as being logical and expected from the brand, that is when the brand conveys a sought benefit in its new category of extension products.

While Park et al., (1991) define congruence as being the process of categorization through which we judge whether the product fits with its category, Lane (2000) singles out two major variables which intervene in the level of elaboration: the lack of congruence or "the measure where by a brand extension is surprising or unexpected", and the "fit" used in the meaning of coherence.

As for co-branding, Park et al. (1996) postulate that congruence is the complementarity between the brands under three conditions:

- They have in common a set of attributes that are pertinent but necessarily salient.

- They differ in terms of attribute salience, what is salient for one is not for the other.

- The brand for which the attribute is salient is better evaluated than the one for which it is not.

The words used are different; they can correspond to antecedents or to some consequences of congruence. However, they eventually describe the fact that two entities fit together well: it can be the new product's brand 
and category, or two brands which are associated over a new product.

\section{Congruence in advertising}

The notion of congruence equally appears in advertising. It is dealt with in two fields:

- Publicizing celebrities as spokespersons: Advertizing executives use a celebrity to benefit from his or her fame and gain a better memorization of the advertisement, which entails a better recognition of the associated brand. In this context, the authors often refer to congruence as a tool of persuasion (Kamins and Gupta, 1994) or to a "match up effect" (Lynch and Schuler, 1994).

- Advertising through visual and textual elements:

Hechler and Childers (1992) have pondered over congruence among the visual and textual elements of an advertisement. Congruence is defined according to two dimensions: pertinence and the expected side. Pertinence shows how much the information contained in the stimulus contributes to or hinders a clear identification of the theme or the message. The expected side refers to the degree to which an item or a piece of information falls within a predetermined scheme or a structure evoked by this theme.

The impact of the congruence between brand personality and self-image on the consumer's satisfaction and loyalty: Developing a model and hypotheses.

Many researchers have investigated the effects of the congruence between the brand personality and self-image on the consumer's behavior (Levy, 1959; Dolich, 1969; Landon, 1979; Sirgy et al., 1997; Park and Lee, 2005; Sung et al., 2005). According to the theory of congruence with self-image, part of the individual's behavior is accounted for by the comparison between his own self-image and the brand's image as reflected by the stereotype user of the brand (Sirgy, 1986; Sirgy et al., 1997).
The effect of congruence between brand personality and self-image on satisfaction:

The consumer's satisfaction is treated as a fundamental notion in marketing. It is defined as the global evaluation done after a choice related to a specific purchase decision. (Day, 1984; Westbrook and Oliver, 1991). For Achour (2006) satisfaction is defined as "a positive feeling a consumer has after a consumption experience, and springing out of a comparison between the expectations from a product or a service and the performance perceived from it.

Many researchers have conducted studies on the effect of the congruence between brand personality and self-image on the consumer's satisfaction. Most of these researchers have focused on the post-purchase behavior (Sirgy, 1986; Richins, 1991; Graeff, 1997).

Concerning brand personality, Ferrandi and Valette-Florence (2002a, 2002b) have found a strong attraction between some human personality features and those of the similar brand.

According to Ouwersloot and Tudorica (2001), companies should consider brand personality as a tool that enables them to reach their satisfaction objective. Chon (1990), and Jamal and Goode (2001) have investigated the field of tourism services, relying on Sirgy's (1985) congruence theory. They have studied the direct effect of congruence with self-image on satisfaction. A significant positive relationship appeared to exist between the two concepts. Park and Lee (2005) have brought to the fore this significant positive influence of congruence between brand personality and human personality, when it comes to the consumers' satisfaction towards the targeted brand. Therefore, taking these research works into consideration, we can state the following hypothesis:

H1/ The congruence between the brand personality and the consumer's self-image has a positive impact on satisfaction towards a brand. 


\section{The effect of the consumer's satisfaction towards a brand on loyalty to this brand}

Loyalty to a brand is conceptualized as being the intention to purchase a brand or a product and to encourage others to do so (Lau and Lee, 1999). For Walters et al., (1989), loyalty is "the consumer's propensity to buy the same product (brand) or to frequent the same shop whenever he needs this product". It comes out from this definition that loyalty is a routine purchasing behavior. It is perceived as a positive result of a recurrent relation between buyer and seller. Others suggest that the concept of loyalty can be described as the attachment of some customers to a brand (Roux, 1986). According to them, loyal consumers are emotionally attached to a brand and often buy it. However, according to Achour (2006), loyalty and attachment to a brand are not always synonyms. The author adds that "some consumers who are loyal to a brand are not necessarily attached to it: it is the case of those customers who are loyal to a brand because they have no other alternative (limited financial resources, availability of the brand, appropriateness of the shop where they go shopping, etc.)".

The literature on loyalty to a brand distinguishes two types of approaches to this concept: a behaviorist or operational approach which keeps the behavioral dimension of loyalty. According to this approach, the consumer is loyal when he regularly buys the same brand (Achour, 2006).Yet this approach suffers some failings, namely the fact that it does not take into account the attitude component of loyalty. Following the shortcomings of the behavioral approach, a cognitive or conceptual approach is keenly observing the intentional side of loyalty. This approach suggests that in order to qualify a recurrent buyer as loyal, it is equally convenient to be sure that he has developed a favorable attitude towards the brand. This would single out loyalty from others types of identical purchase. Consequently, according to the attitude approach, loyalty is accounted for by the consumers' favorable attitudes towards a product or a brand, and is expressed through consumption acts (Trinquecoste, 1996). This attitude component is often measured through attitude scales (cognitive loyalty) (Jacob and keyner, 1973; Dufer and Moulins, 1989).

Many researchers have investigated the relationship between satisfaction and loyalty to a brand. They have shown that the consumers' satisfaction towards a brand is a guarantor for their loyalty (Magin et al., 2003; Park and Lee, 2005; Achour, 2006). Thus, loyalty could be considered as a consequence of satisfaction (Oliver, 1980). Besides, several researchers (Oh and Park, 1998; Zeithmal et al., 1996) think that the consumer's recurrent purchase behavior is always affected by the degree of his satisfaction with a product or a service that he buys.

Cronin and Taylor (1992) suggest that the consumer's satisfaction has a significant effect on the purchase intention of industrial services. Bitner (1990) states that the consumer's satisfaction towards a given brand has a direct effect on loyalty to this brand. Oliver (1980) and Kotler (2000) postulate that satisfaction affects attitudes positively. In the same context, Oliver and William (1983) suggest that the consumers' satisfaction affects their attitudes after their decision, their preferences towards a brand as well as their future intentions. Thus, the following hypotheses could be drawn:

H2a: the consumer's satisfaction towards a brand has a positive effect on his attitude towards this brand.

H2b: The consumer's satisfaction towards a brand has a positive effect on the level of his preference of this brand.

H2c: The consumer's satisfaction towards a brand has a positive effect on his intention of future behavior towards this brand.

\section{The effect of the congruence between the brand personality and self-image on loyalty to the brand}

Within the framework of brand personality, several researchers have shown that this variable is positively linked to the consumers' loyalty (Fournier, 1998; Yi and La, 2002). It has been demonstrated that the brand personality has a significant positive impact on the attitude of consumers towards this brand (Helgeson and 
Supphellen, 2004; Ben Slimane et al., 2005; Ambroise et al., 2005) and their future intentions and behavior (Ambroise, 2006; Morschett et al., 2007).

Many researchers have pointed at the positive influence of the brand personality on the consumers' preferences towards this brand (Sirgy, 1982; Jamal and Goode, 2001; Wee, 2004; Ambroise, 2006). However, only a few research works have developed research empirical protocols to demonstrate this influence.

Moreover, several researchers have conducted studies on the effect of congruence of the image on the attitude of the brand's consumer in terms of behavioral responses (Onkvisit and Shaw, 1989; Sirgy and Samli, 1985). All of these studies agree on the fact that the consumer prefers the product the image of which is congruent with his self-image. In other words, consumers only have a favorable attitude towards a specific brand after applying a set of personality attributes and linking them to their self-images. According to the image congruence theory by Sirgy (1985), when the image of the brand is perceived as similar to the consumer's self-image in terms of personality attribute types, the consumer tends to develop a favorable attitude towards the brand when deciding about a purchase act, or about buying a product again.

Govers and Schoormans (2005) and Wee (2004) have shown that congruence between brand personality and human personality is significantly influential on consumers towards the targeted brand. In other words, consumers often prefer the brands or the products which have a high level of congruence with self-image (Sirgy, 1986; Sirgy et al., 1997, Phau and Lau, 2001).

Relying on these different works, we propose the following hypotheses:

H3a: Congruence between brand personality and the consumer's self-image has a positive effect on his attitude towards this brand.

H3b: congruence between brand personality and the consumer's self-image has a positive impact on his level of preference towards this brand.

H3c: congruence between brand personality and the consumer's self-image has a positive effect on his intention of future behavior towards this brand.

The conceptual model and the different hypotheses of the research are illustrated in Figure 1.

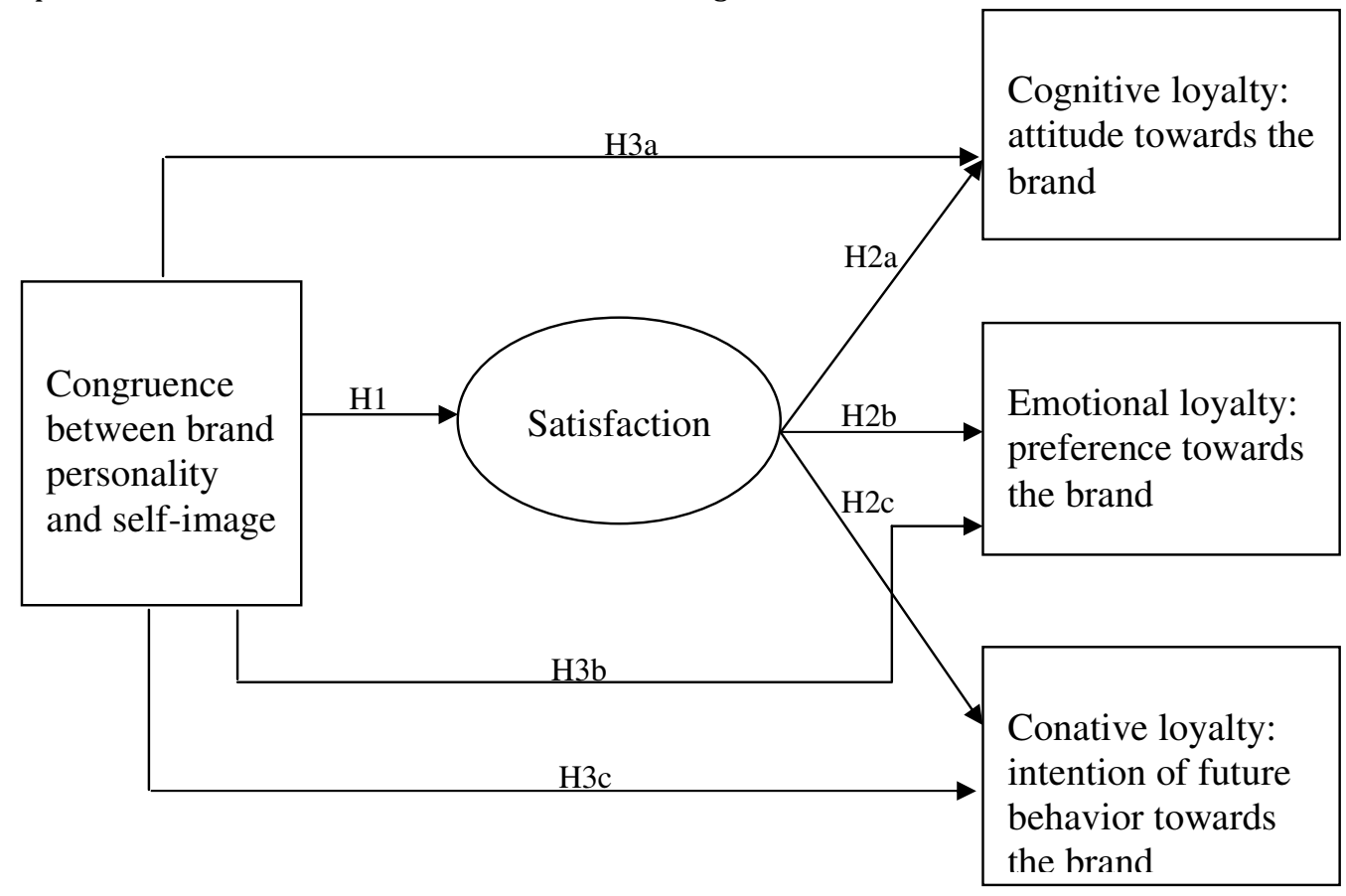

Figure 1: conceptual model 


\section{Conclusion}

Although the number of articles on the congruence between brand personality and selfimage has noticeably increased lately, researchers still unanimously deplore the limited amount of investigation in this topic, as compared with the research dealing with brand personality, for instance. This works aims at enriching the field.

This article represents dual interest to academic and managerial fields.

From an academic standpoint, this research aims at a double contribution: clarifying the concept of congruence between brand personality and self-image on the one hand, and elucidating its effect on the customer's satisfaction and loyalty to the brand on the other.

The current study wishes to show the crucial role of the congruence variable in the relationship between the brand and the consumer.

From a managerial perspective, congruence between brand personality and self-image is an important concept which companies should take into account in order to develop and better manage their brand. Indeed, the existence of a link between the brand personality and the consumer's self-image provides marketing executives with the opportunity to have a strategic tool which enables them to improve or strengthen the mapping of their brands. This would attract consumers who are sensitive to the personality features displayed or who wish to use them as a vehicle of the conception they have of themselves.

Yet, our work did not go beyond a simple literature review. It would be worthwhile to develop the research empirical protocols so as to show how the congruence between brand personality and self-image affects the level of consumer satisfaction and his loyalty towards a brand.

\section{References}

Aaker J.L. (1997), «Dimensions of brand personality », Journal of Marketing Research, Vol 34, $\mathrm{N}^{\circ} 3$, pp 347-356.

Aaker J.L., Benet-Martinez V. et Garolera J. (2001), « Consumption symbols as carries of culture, A study of Japanese and Spanish brand personality conctructs», Journal of Personality and Social Psychology, Vol 21, №3, pp 249-264.

Achour L. (2006), «La relation entre la satisfaction et la fidélité à la marque : une étude empirique après des consommateurs tunisiens de yaourts », La Revue des Sciences de Gestion, N²22, Nov/Déc, p 61.

Achouri M. A. et Bousalama N. (2009), «L'efficacité du parrainage sur Internet en termes d'attitude à l'égard du parrain: Rôle de la congruence », 12ème conférence IBIMA, 29-30 Juin 2009, Kuala Lumpur, pp 496-512.

Ambroise L. (2006), «La personnalité des marques : une contribution réelle à leur gestion ", Revue Française du Marketing, Vol 207, $\mathrm{N}^{\circ} 2 / 5$, pp 25-41.

Ambroise L., Ben Sliman S., Bourgeat P., De Barnier V., Ferrandi J-M., Merunka D., Roehrich G. et Valette-Florence P. (2005), « The impact of brand personality on attitude and commitment towards the brand », La Londe - Les Maures.

Ambroise L., Ferrandi J-M., Merunka D. et Valette-Florence P. (2004), « La personnalité des marques explique-t-elle le choix des marques? Un test de la validité prédictive du baromètre de la personnalité des marques", Actes du XXe Congrès AFM, 6-7 mai, Saint Malo, CD-ROM.

Ambroise L., Ferrandi J-M., Valette-Florence P. et Merunka D. (2003), "Première application du baromètre de mesure de la personnalité de la marque à deux enseignes françaises ", Actes du $6^{\circ}$ Colloque Etienne Thil, 25-26/09, La Rochelle, CD-ROM.

Azoulay A. and Kapferer J.N. (2003), « Do brand personality scales really measure brand 
personality », Brand Management, Vol 11, N², pp 143-155.

Bahria H. et Bousalama N. (2009), "L'influence de la personnalité de la marque sur l'attitude d'achat du consommateur: Une étude modérée par une caractéristique individuelle permanente: le concept de soi», 12ème conférence IBIMA, 29-30 Juin 2009, Kuala Lumpur, pp 577-590.

Bauer H.H., Mader R. and Keller T. (2000), «An investigation on the brand personality scale assessment of validity and implications with regards to brand policy in European cultural domains», Multicultural Marketing Conference, Academy of Marketing science, Hong-Kong.

Belk R.W. (1988), "Possessions and the extended self», Journal of Consumer Research, Vol 15, pp 139-149.

Ben Sliman S., Ferrandi J-M., Merunka D. et Valette-Florence P. (2005), "L'influence de la personnalité de la marque sur le comportement du consommateur : modélisation et application à de grandes enseignes d'hypermarchés en France

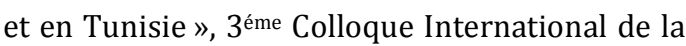
Recherche en Marketing, Association Tunisienne du Marketing, 1-2 avril, Hammamet.

Benavant C. (1995), «Portefeuille clients : une application au marché de Benelux», Décisions Marketing, $\mathrm{N}^{\circ} 4$, p 45.

Berry N.C. (1988), «Revitalizing brands», Journal of Consumer Marketing, Vol 15, Eté, pp 15-20.

Biel A. (1993), Converting image into equity, Brand equity and advertising, éds Aaker et Biel, Hillsdale, NJ: Lawrence Erlbaum Associates, 6782.

Bitner M.J. (1990a), «Evaluating service encounters, the effect of physical surroundings and employees responses » Journal of Marketing, Vol 54, pp 69-82.

Bitner M.J. (1990b), « Servicescapes : the impact of physical surroundings on customers and employees » Journal of Marketing, Vol 54, pp 5771.
Brée, J. (1994), «Le comportement du consommateur », Collection Que-sais-je?», PUF, pp 101-103.

Brunel M.L. (1990), «Introduction à la conscience de soi et au concept de soi, tels qu'on les perçoit depuis William James», Revue Québécoise de Psychologie, Vol 11, N¹-2, p79.

Caprara G.V., Barbaranelli C. et Livi S. (1994), «Mapping personality dimension in the Big Five model », European Review of Applied Psychology, Vol 44, N¹, pp 9-15.

Caprara G.V., Barbaranelli C. et Livi S. (2001), «Brand personality: How to make the metaphor fit», Journal of Economic psychology, Vol 22, N³, pp 377-395.

Chon K.S. (1990), «Consumer satisfaction and dissatisfaction in tourism as related to destination image perception», Ph.D. Dissertation; Virginia Tech University.

Cloninger S.C. (1999), «La personnalité », Flammarion (traduit de l'américain, Cloninger S.C. (1996). Personality, description, dynamics and developpement), W.H. Freemen and Company.

Costa P.T.J et McCrae R.R. (1998), «Traits theories of personality», Advanced personality, eds. Barone, Hersen et Van Hasselt, Plenum Press, New-York, pp 103-121.

Crimmins J. and Horn M. (1996), « Sponsorship: from management ego tip to marketing success. ", Journal of Advertising Research, 36, 4, pp11-21.

Cronin J.J. and Taylor S.A. (1992), « Measuring service quality. A re-examination and extension», Journal of Marketing, Vol 56, pp 5568.

D'Astous A. and Bitz P. (1995), « Consumers evaluations of sponsorship programmes», European Journal of Marketing, 29, 12, pp 6-22.

D'Astous A. and Bitz P. (2003), "A scale for measuring store personality», Psychology and Marketing, Vol 20, N5, pp 455-496.

D'Astous A., Said I et Levesque M. (2002), «Conception et test d'une échelle de mesure de la personnalité des magasins », Actes du Congrès 
de l'Association Française de Marketing, 18, Lille, pp 115-130.

Day R.L. (1984), «Modeling choices among alternative responses to dissatisfaction», Advances in Consumer Research, 11, pp 496-499.

Diamantopoulos A. Smith G. and Grima I. (2005), «The impact of brand extensions on brand personality: experimental evidence», European Journal on Marketing, Vol 39.

Dich A., Dipankar C. and Gabriel B. (1990), «Memory based inference during consumer choise», Journal of Consumer Research, Vol 17 June, pp 82-93.

Digman J.M. (1990), «Personality structure: emergence of the five-factor model», Annual Review of Psychology, Vol 41, pp 417-440.

Dolich I.J. (1969), «Congruence relationships between self images and product brands», Journal of Marketing Research, Vol 6, N¹, pp 8084.

Dufer J. et Moulins J.L. (1989), «La relation entre la satisfaction du consommateur et sa fidélité à la marque : un examen critique ", Recherches et Applications en Marketing, $\mathrm{Vol} 4, \mathrm{~N}^{\circ} 2$, pp 21-36.

Durgee J.F. (1988), « Understanding brand personality », Journal of Consumer Marketing, Vol 5, Eté, pp 21-25.

Ferrandi J.M. et Valette-Florence P. (2002a), «Premier test et validation de la transposition d'une échelle de personnalité de personnalité humaine aux marques", Recherches et Applications en Marketing, Vol 17, N³, pp 21-40.

Ferrandi J.M. et Valette-Florence P. (2002b), « Le transfert d'une échelle de personnalité humaine réduite à la marque», Journées Thématiques AFM-IRG, Paris.

Ferrandi J.M., Fine Falcy S. et Valette-Florence P. (1999), «L'échelle de personnalité des marques de Aaker appliquée au contexte français: Un premier test », Actes de congrès de l'Association Française de Marketing, Strasbourg, 15, pp 1089-1112.

Fleck - Dousteyssier N. (2005), « La congruence dans le parrainage: définition, rôle et mesure»,
Actes du XXI ${ }^{\circ}$ Congrès AFM, 18-20 Mai, Nancy, pp 7-12.

Fleck-Dousteyssier N. (2004), «Une application des modèles de traitement de l'information au parrainage : rôle de la congruence », Actes de la 1 ère journée thématique du Nord-East de la France sur la communication marketing.

Fleck-Dousteyssier N. (2006) «Effet du parrainage sur les réactions affectives et cognitives du consommateur envers la marque : le rôle de la congruence", Recherches et Applications en Marketing, Vol 21, N4, p104.

Fournier S. (1998), «Consumers and their brands: developing relationship theory in consumer research", Journal of Consumer Research, Vol 24, N4, pp 343-373.

Funder D.C. "Personality», Annual Review of Psychology, Vol 52, pp 197-221.

Galan J.P. (2007), « Proposition d'une échelle de mesure de la congruence entre la musique et le concept de soi ", Actes du XXIIIème Congrès International de l'AFM, Aix-les-Bains

Goldberg L.R. (1990), «An alternative "description of personality": the big five factor structure», Journal of Personality and Social Psychology, 59, 6, 1216-1229

Gouteron J. (2006), «L'impact de la personnalité de la marque sur la relation marque consommateur, application au marché du prêt-àporter féminin », Revue Française du Marketing, Avril, Vol 207, pp 43-59

Govers P.C.M. and Schoormans J.P.L. (2005), «Product personality an dits influence on consumer preference », Journal of Consumer Marketing, Vol 22, N4, pp 189-197.

Graeff T.R. (1996), «Using promotional messages to manage the effects of brand and self image on brands evaluations», Journal of Consumer Marketing, Vol 13, №3, pp 4-18.

Gwinner K. P. and Eaton J. (1999), «Building brand image through event sponsorship: the role of the image transfert. », Journal of Advertising, Vol 28, N, Winter, pp 47-57

Heckler S. E. and Childers T. L. (1992), « The role of expectancy and relevancy in memory from verbal and visual information: what is 
incongruency? », Journal of Consumer Research, Vol 18, N²4, March, pp 475-492.

Helgeson J.G. and M. Supphellen (2004), «A Conceptual and measurement camparison of self congruity and brand personality», International Journal of Market Research, Vol 46, №2, pp 205233.

Huteau M. (1985), « Les conceptions cognitive de la personnalité», Presses Universitaires de France.

Jacoby J. et Keyner D.B. (1973), «Brand loyalty vs Repeat purchasing behaviour», Journal of Marketing Research, Vol 10, February, pp 1-9.

Jamal A. and Goode M.M.H. (2001), « Consumers and brands: a study of the impact of self image congruence on brand preference and satisfaction», Marketing Intelligence \& Planning, Vol 19, N7, pp 482-492.

Johar L. E. and Pham M. T. (1999), «Relatedness, prominence, and constructive sponsor identification», Journal of Marketing Research, Vol, 36, N³, August, pp299-312.

John O.P. (1990), «The "Big Five" factor taxonomy: dimensions of personality in the natural language and in questionnaires», in L.A. Pervin (ed.), Handbook of personality: theory and research, London, New York, Guilford press pp 66-100.

Kamins M. A. and Gapta K. (1994) «Congruence between spokesperson and product type: a mutch up hypothsis perspective», Psychology and Marketing, Vol 11, Nㅜ, pp 569-586.

Koebel M.N. et Ladwein R. (1999), « L'échelle de personnalité de la marque de Jennifer Aaker: Adaptation au contexte français », Décisions Marketing, Vol 16, pp 81-88.

Kotler Ph. (2000), «Marketing management», the millennium edition, Prentice-Hill.

L’Ecuyer R. (1978), « Le concept de soi », Paris, PUF, p24.

L'Ecuyer R. (1994), « Le développement du concept de soi, de l'enfance à la vieillesse », les Presses de l'Université de Montréal, Montréal, p45.
Landon E.L.J.R (1979), " Self concept, ideal self concept, and consumer purchase intentions», Journal of Consumer Research, Vol 1, pp 44-51.

Lane V. R. (2000), « The impact of ad repetition and ad content on consumer perceptions of incongruent extensions», Journal of Marketing, 64, April, pp 80-91.

Lau G.T. and Lee S.H. (1999), «Consumers'trust in a brand and the link to brand loyalty », Journal of Market Focused Management, Vol 4, pp 341370.

Levy S.J. (1959), "Symbols for sale », Harvard Business Review, Vol 37, July-August, pp 17-24.

Levy S.J. (1985), « Dreams, Fairy Tales, Animals and Cars », Psychologie et Marketing, Vol 2, Eté, pp 67-81.

Louis D. (2005), «Le parrainage sur Internet: mode de fonctionnement et influence de la similarité perçue entre l'entité parrainée et le parrain », Revue Française de Marketing, Paris, $N^{\circ} 205$, pp 41-71.

Lynch M. A. and Shuler D. (1994), « The match up effect of spokesperson and product congruency: a schema theory interpretation », Psychology and Marketing, Vol 11, $\mathrm{N}^{\circ}$, September- October, pp 417-445.

Magin S., Algesheimer R., Huber F. et Herrmann A. (2003), The impact of brand personality and customer satisfaction on customer's loyalty: theoretical approach and findings of a causal analytical study in the sector of Internet service providers, Electronic Markets, Vol 13, N4, 294308.

Morschett D., Jara M., Schramm-Klein H. and Swoboda B. (2007), «Retail Brand Personality as Influence Factor on store Loyalty - An Empirical Test of an Integrative Model», Emac Proceedings, CD-ROM.

Munson J.M. and Spivey W.A. (1981), «Relation between social class and three aspects of self concept: actual, ideal and egocentric self», Journal of Social Psychology, Vol 119, N¹, p 85.

Oh H. and S.C. Parks (1997), «Customer satisfaction and service quality: critical review of the literature and research implications for the hospitality industry», Hospitality Research Journal, Vol 20, ํ3, pp 35-64. 
Oliver R. and William O.B. (1983), «The role of involvement in satisfaction process», Advances in consumer research, $\mathrm{Vol} 10, \mathrm{~N}^{\circ} 1$, pp 250-255.

Oliver R.L. (1980), "A cognitive model of antecedents and consequences of satisfaction decision », Journal of Marketing Research, Vol 20, $\mathrm{N}^{\circ} 3$, pp 44-51.

Onkvisit S. and Shaw J.J. (1989), «Service marketing: image and branding and competition», Business Horizons, pp 13-18.

Ouwersloot H. and Tudorica A. (2001), «Brand personality, creation through advertising», MAXX Working Paper Series, 2001-01.

Park C. W., Jun S. Y. and Shucker A. D. (1996), « Composite branding alliances: an investigation of extension and feedback effects», Journal of Marketing Research, 33, November, pp 453-466.

Park C. W., Milberg S. and Lawson R. (1991), «Evaluation of brand extensions: the role of product feature similarity and brand concept consistency», Journal of Consumer Research, Vol 18, September, pp 185-193.

Park S.Y. and Lee E.M. (2005), Congruence between brand personality and self-image, and the mediating roles of satisfaction and consumer-brand relationship on brand loyalty, Asia-Pacific Advances in Consumer Research, Vol 6, 39-45

Phau I. and Lau K.C. (2001), «Brand personality and consumer self-expression: single or dual carriageway? », Brand Management, Vol 8, №6, pp 428-444.

Piéron H. (1994), «Vocabulaire de la

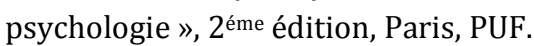

Plaisant 0., Srivastava S., Mendelsohn G.A., Debray Q. et John O.P. (2005), « Relations entre le Big Five Inventory français et le manuel diagnostique des troubles mentaux dans un échantillon clinique français ", Annales Médico Psychologiques, p2.

Plummer J.T. (1985), « How personality makes a difference », Journal of Advertising Research, Vol $24, \mathrm{~N}^{\circ} 6$, pp 27-31.
Richins M.L. (1991), «Social comparison and the idealized image of advertising », Journal of Consumer Research, Vol 18, pp 71-88.

Rodgers C.R. (1959), «Conditions suffisantes et nécessaires d'un changement de personnalité en psychothérapie » ", Hommes et techniques, $\mathrm{N}^{\circ} 169$, pp 150-157.

Rodgers S. (2004), "The effects of sponsor relevance on consumer reactions to Internet sponsorship», Journal of Advertising, Vol 32, $\mathrm{N}^{\circ} 4$, p 68.

Resenberg M. (1979), "Conceiving the self », Basic Books, New York.

Roux J. (1986), «L'influence de la marque dans le comportement du consommateur ", Thèse pour la Doctorat en sciences de Gestion, Université de Paris I, Panthéon-Sorbone.

Samama A. (2003), «De l'importance aujourd'hui de passer de la marque image à la marque relation », Revue Française du Marketing, Vol 2-3/5, Nº192/193, pp 73-88.

Saucier G. (1994), «Mini-markers: A brief version of Goldberg's unipolar big-five markers», Journal of Personality assessment, $\mathrm{Vol} 63, \mathrm{~N}^{\circ} 3, \mathrm{pp}$ 506-516.

Sigaw J.A., Mattila A. and Austin J.R., «The brand personality scale: An application for restaurants», Hotel and Restaurant Administration Quarterly, June, pp 48-55.

Sirgy M.J. (1982), «Self-concept in consumer behaviour: a critical review», Journal of Consumer Research, Vol 9, N3, pp 287-300.

Sirgy M.J. (1985), «Self image/Product image congruity and consumer decision making», International Journal of Management, $\operatorname{Vol} 2, \mathrm{~N}^{\circ} 4$, pp 49-63.

Sirgy M.J. (1986), «Using self-congruity and ideal congruity to predict purchase motivation», Journal of Business Research, Vol 13, Nㅜ1, pp 195206.

Sirgy M.J. and Samli A.C. (1985), «A path analytic model of store loyalty involving self-concept, store image, socioeconomic status and 
geographic loyalty», The Journal of the Academy of Marketing science Vol 13, pp 265-291.

Sirgy M.J. et Su Ch. (2000), «Destination image, Self congruity and travel behavior: toward an integrative model», Journal of Travel Research, Vol 38, May, pp 340-352.

Sirgy M.J., Grewal D. and Mangleburg T.F. (2000), «Retail environment, Self congruity and Retail patronage: An integrative model and a research agenda», Journal of Business Research, Vol 49, pp 127-138.

Sirgy M.J., Grewal D., Mangleburg T.F., Park J.-O, Chon K-S, Claiborne C.B., Johar J.S. et Berkman H. (1997), «Assessing the predictive validity of two methods of measuring self-image congruence», Journal of the Academy of Marketing Science, Vol 25, N³, pp 229-241.

Smaoui F. (2006), «La mesure de la personnalité de la marque dans le contexte tunisien: proposition d'une échelle de mesure : premiers résultats ", 4éme Colloque International de la Techerche en Marketing, Association Tunisienne de Marketing, Mai 2006.

Speed R. and Thompson P. (2000), "Determinants of sponsorship response. ", Journal of the Academy of Marketing science, 28, 2, pp 226-238.

Sung Y-S., Park E. and Han M-K. (2005), «The influences of the brand personality on brand attachment and brand loyalty: centered on the differences between the brand community members and non members», Asia - Pacific Advances in Consumer Research, 6, 156.

Tauber E. M. (1988), « Brand leverage: strategy for growth in a cost - control world», Journal of Advertising Research, September, pp 26-30.

Trendel O. et Warlop L. (2006), « Mémorisation implicite des parrains : avantages aux parrains non congruents. », Actes du XXII ${ }^{\circ}$ Congrès AFM, 11-12 Mai, Nantes, p4.

Trinquecoste J.F. (1996), «Fidéliser le consommateur: un objectif commercial prioritaire », Décisions Marketing, N7, JanvierAvril, pp 17-23.

Vernette E. (2003), « Personnalité de la marque et image de soi », Les tendances du Marketing, ESCP-EAP, pp 1-21.
Vernette E. (2008), « Les atouts et les pièges de la personnalité de la marque», Décisions Marketing, Vol 49, Jan-Mar, p 24.

Viot C. (2003) «Personnalité de la marque: Approche comparative», Actes du Congrès International de l'Association Française du Marketing.

Viot C. (2006) «Personnalité de la marque: la métaphore justifie-elle la transposition d'échelles de personnalité humaine?», 5th International congres «Marketing Trends», Venise.

Walters C.G., Bergiel B.G. and Sheth J.N. (1989), «Consumer behavior : A decision-marketing approach. South-Western publishing CO.

Wee T. (2004), «Extending human personality to brands: the stability factors, Brand Management», Vol 11, N²4, pp 317-330.

Westbrook R.A. and Oliver R.L. (1991), «The dimensionality of consumption emotion patterns and consumer satisfaction», Journal of Consumer Research, 18, June, 84-91

Yi Y.J. and La S.N. (2002), Brand PersonalityBrand Identification-Brand Equity Model: An Exploratory Study on the Difference Between Users vs. Non-Users, Korean Marketing Review, Vol 17, $\mathrm{N}^{\circ} 3$, pp 1-34.

Zeithaml V.A., Berry L.L. and Parasuraman A. (1996), « The behavioral consequences of service quality», Journal of Marketing, Vol 60, April, pp 31-46.

Zinkhan G.M. and Hong J.W. (1991), «Self concept and advertising effectiveness: A conceptual model of congruency, conspicuousness and response mode», Advances in consumer research, Vol 18, pp 348-354.

Zouaghi S. et Darpy D. (2003), « Du soi au groupe: naissance du concept de nous et exploration d'une échelle de mesure de nous idéal ", Recherches et applications en Marketing, Vol 18, $\mathrm{N}^{\circ} 4$, pp 3-22. 